\title{
First report of Eimeria sp. from Eurasian wild boar (Sus scrofa) in Iran
}

\author{
Shahrokh Shirazi*, Arash Motaghedi and Moslem Safari
}

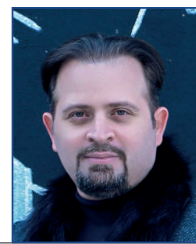

\section{Abstract}

In Iran, wild boar is distributed throughout the country, except the Central Desert. One of the important habitats of this animal is the northern mountainous area. They may pass infected faeces in these areas, which can lead to zoonotic disease, though information about parasitic infections in wild boar is rare in Iran and further study is necessary. In February 2019, a wild boar carcass was submitted to the Veterinary Parasitology Department of the Science and Research University of Tehran by the Department of Environment of Mazandaran province in order to study its parasitic infections. Faeces and the gastrointestinal tract were separated and their contents were tested using two flotation methods (Willis and Clayton-Lane), and the samples were referred to the Parasitology Laboratory of Urmia University for further study. The sample was infected with Eimeria protozoa; Eimeria porci and Eimeria neodebliecki were diagnosed based on the size and morphology factors of the isolated oocysts. This is the first report of wild boar infection by Eimeria sp. protozoa in Iran.

Key words: Eimeria; Infection; Iran; Oocyst; Sus scrofa

\section{Introduction}

The Eurasian wild boar (Sus scrofa) is widely distributed worldwide (Jemeršić et al., 2019), inhabiting vast areas in Eurasia and Northern Africa (Ashrafzadeha et al., 2018). The Eurasian wild boar lives in dense populations in different parts of west, south and southwest, north and northeast forests of Iran (Mansouri et al., 2016) (Fig. 1). They usually cause destruction of crops and are often hunted by farmers or some predator species such as leopard (Panthera pardus), brown bear (Ursus arctos), wolf (Canis lupus) and Eurasian lynx (Lynx lynx) (Ashrafzadeha et al., 2018; Dodangeh et al., 2018; Yaghoobi et al., 2016).

Protozoans that may be transmitted from boars to human are mainly Balantidium coli, Entamoeba polecki, Blastocystis, Giardia, Cryptosporidium, and Toxoplasma gondii, (Yaghoobi et al., 2016). However, due to food habits and religious advice for Muslims) pig breeding and pork consumption are forbidden, (these

Shahrokh SHIRAZI*, (Corresponding author: e-mail: sh.shirazi@srbiau.ac.ir), Arash MOTAGHEDI, Department of Pathobiology, Faculty of Veterinary Medicine, Science and Research Branch, Azad University, Tehran, Iran; Moslem SAFARI, Department of Pathobiology, Faculty of Veterinary Medicine, Shahid Chamran University of Ahwaz, Ahwaz- Iran 
diseases are less significant in these communities (Maleki et al., 2019).

A broad spectrum of Eimeria species is the cause of coccidiosis in wild boar. The most important species are $E$. perminuta, E. spinosa, E. suis, E. porci, E. scabra, E. cerdonis, E. neodebliecki and E. debliecki (Bowman, 2020). Wild boars are considered potential reservoirs of several zoonotic diseases and there is a little data available on parasitic infections in wild boars in Iran (Eslami and Farsad-Hamdi, 1992), though most studies have focused on the helminth parasites of wild boar (Dodangeh et al., 2018). In practice, studies on boar

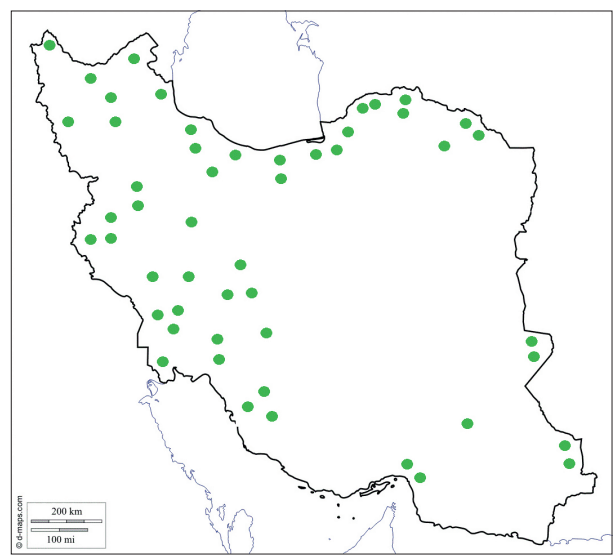

Fig. 1. Distribution of Iranian wild boar: green dots (7) protozoa are very limited and therefore this study was carried out to identify the protozoans of the Eurasian wild boar.

\section{Material and methods}

The study was carried out in Mazandaran Province, in northern Iran, located on the southern coast of the Caspian Sea. This province covers an area of $23,842 \mathrm{~km}^{2}$ with a moderate, subtropical climate and an average temperature of $25^{\circ} \mathrm{C}$ in summer and about $8^{\circ} \mathrm{C}$ in winter. The highlands in the southern part of this province are suitable habitat for wild boar and other wild animals (Fig. 2).

In February 2019, the Department of Environment of Mazandaran Province submitted a carcass of wild boar to the Parasitology Laboratory, Faculty of Veterinary Medicine, Science and Research Branch of the University of Tehran, in order to study its parasitic infections. Unfortunately, the sample was sent in formalin solution, which made it impossible to extract DNA for molecular techniques due to the kits available in Iran, and only morphology was used to identify this protozoan. The carcass was then necropsied and the faeces were removed from the intestines.

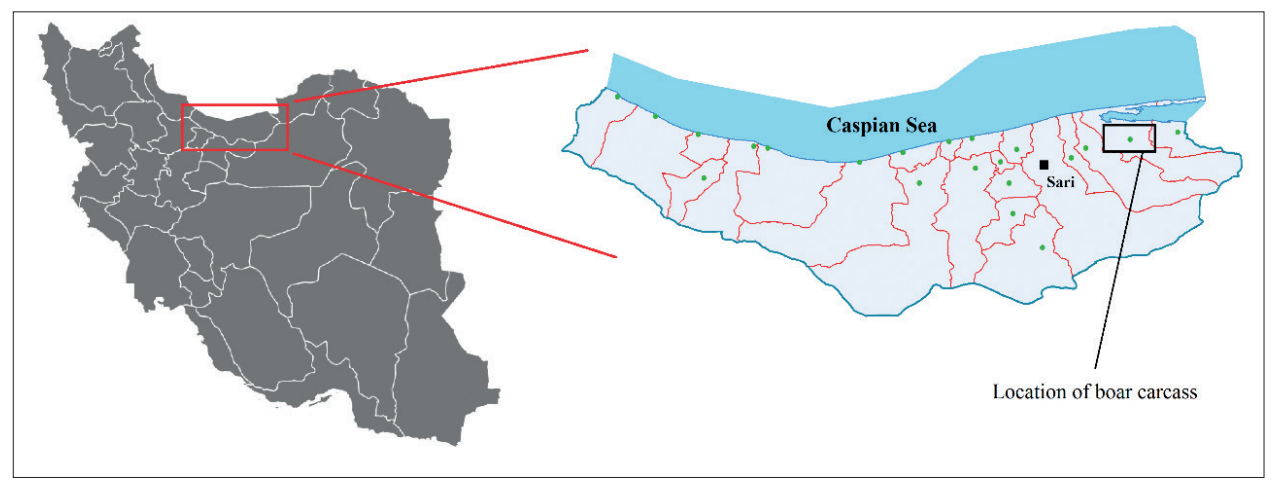

Fig. 2. Map of Mazandaran Province, northern Iran and location of the analysed boar carcass 
To identify of protozoan oocysts, two flotation methods were used. The first was the Willis method, which is a qualitative method and very useful in primary surveys. A faeces sample (2 g) was suspended in $100 \mathrm{~mL}$ saturated sodium chloride solution and it was gently mixed and filtered by a tea strainer into a Willis tube, and the tube was filled to the top with the flotation solution and topped with a cover glass. The cover glass was picked up quickly after 10-20 $\mathrm{min}$, and examined by light microscope (Soulsby, 1982).

The second method was the ClaytonLane method. Briefly, $5 \mathrm{~g}$ faeces were mixed with $40 \mathrm{~mL}$ water in the blender for approximately 2-3 minutes and then passed through a mesh sieve (3inch diameter). After stirring, it was dissolved as a $15 \mathrm{~mL}$ solution in ClaytonLane centrifuge tubes. The sample was centrifuged at 2,500 $\mathrm{g}$ for 2 minutes and the supernatant was discarded. Saturated Scheater solution was added to the tube and the precipitate was thoroughly mixed. The tube was topped with a cover glass and then centrifuged. Then the cover glass was removed and observed by light microscope (Castelino and Herbert, 1972).

Some oocysts were seen in both methods and were photographed (Figs. 3 and 4). Some were then measured and

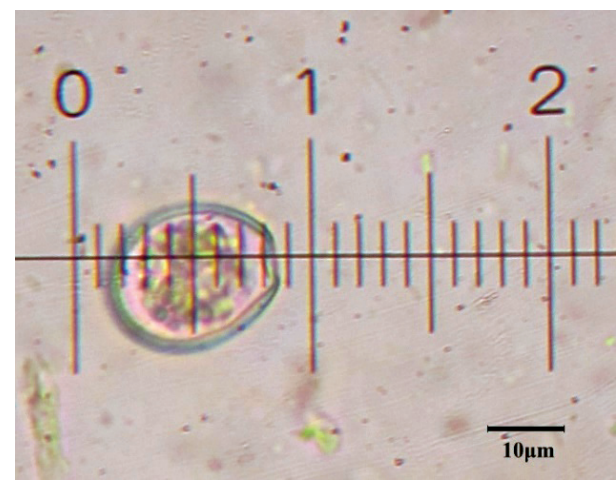

Fig. 3. Oocyst of E. porci (Bar: $10 \mu \mathrm{m}$ ) determined using valid diagnostic keys (Vetterling, 1965; Daugschies et al., 1999). They were also sent for verification to the Parasitology Laboratory of Veterinary Medicine at Urmia University.

\section{Results}

Oocysts were isolated and examined for Eimeria species identification on the basis of their morphometric measures such as: length, width, shape index, and morphology factors such as: shape, wall, colour, micropyle structure, oocyst residuum and stieda body (Soulsby, 1982)

According to the morphology and size of oocysts, diagnostic keys were used to determine that the oocysts belong to the protozoa Eimeria sp., and the oocysts were identified by morphological factors. Eimeria porci oocysts were mostly ovoid with a size of $22.8(18.1-29.3) \times 16.1(13.1-$ 18.7) $\mu \mathrm{m}$. The smooth oocyst wall was colourless to faintly yellow. The oocysts of Eimeria neodebliecki were ellipsoidal $19.2(17.2-21.3) \times 14.9(13.1-18.8) \mu \mathrm{m}$ without a micropyle.

To verify the identification of the sample, they were sent to Urmia University where the morphology and morphometric factors were examined, and those results confirmed the data presented here.

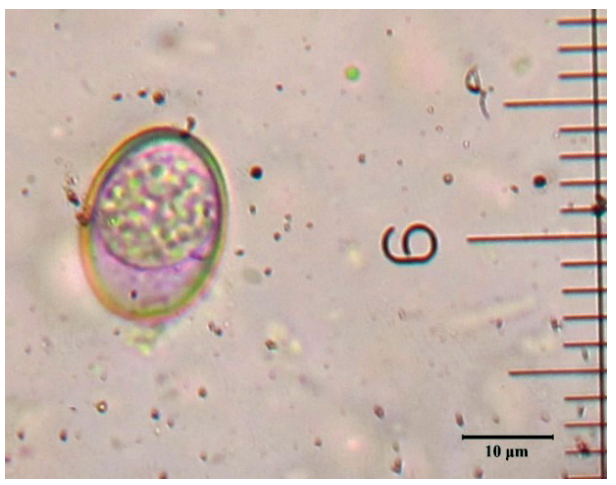

Fig. 4. Oocyst of E. neodeblieki (Bar: $10 \mu \mathrm{m}$ ) 


\section{Discussion}

Protozoan infection especially of Eimeria species in swine occur due to eating infected oocysts excreted by infected hosts. The prevalence of clinical disease attributable to coccidiosis is low and in wild boar and pig emerges clinically in younger ages (Soulsby, 1982). Infections occur worldwide and are usually caused by several species simultaneously. Although most infections are asymptomatic, cases of diarrhoea, weight loss and even fatalities have been described in weaned pigs (Daugschies et al., 2004).

Since this sample sent from the Environment Department of Mazandaran province came from a carcass of an adult male boar hunted by illegal hunters, and there were no reports of porcine coccidian infection in Iran, the aim of this study was only to isolate the boar coccidian oocysts. Two different flotation methods with two different flotation solutions were used to ensure that protozoan oocysts were isolated with high probability. Although molecular methods are now available to identify porcine Eimeria, oocyst morphology remains the most applied and feasible method for differentiation in epidemiological surveys (Daugschies et al., 2004). There are no prior reports of Eimeria sp. infection in wild boar of Iran, and consequently this is the first report in Iran.

Few studies have been conducted in Iran on the identification of wild boar parasites. A 1992 study on 57 boars from different regions of Iran showed helminths infection but with no report of protozoan parasites (Eslami and FarsadHamdi, 1992). For the first time in 2011, the protozoan Sarcocystis miescheriana was reported in the Guilan region (Kia et al., 2011) and infection by the nematode Trichinella murrelli was reported in Iranian wild boar from the same region (Kia et al., 2009). To date, there have been no reports of Eimeria infection in wild boar of western Iran (Solaymani-Mohammadi et al., 2003; Solaymani-Mohammadi et al., 2004).

Eimeria infection was detected in $25.3 \%$ of breeding pigs in Zimbabwe (Chhabra and Mafukidze, 1992) and $52 \%$ in breeding pig herds in Germany (Daugschies et al, 2004). Coccidiosis was estimated in $16.7 \%$ of suckling piglets in China (Zhang et al., 2012) and 3.6\% of pigs of Nigeria (Salifu et al, 1990). Most reports of clinical coccidiosis are in young boars though coccidiosis in adult has also been reported (Yaeger et al., 2003).

Eimeria sp. have been reported from many countries. In Poland, $85.5 \%$ of studied wild boars were infected with Eimeria as a common parasite (Pilarczyk et al., 2004). In Australia, infection with different species of Eimeria were reported in pigs and wild boars and $90 \%$ of cases were infected by more than one species simultaneously (Lowenstein and Kutzer, 1989).

In recent years, the Eurasian wild boar has been seen nearing human settlements in rural areas of Iran, probably due to the destruction of natural wild boar habitats (especially in the forests of northern Iran) and also due to prolonged dryness over the past decade in some southern provinces of Iran. This close proximity with human settlements accelerates the direct contact of wild boars with farmlands, resulting in their contamination with parasites (Dodangeh et al., 2018).

\section{Conclusion}

There are few studies on the infection of wild boars with protozoans and helminths in Iran, though wild boars are known to be reservoir hosts for some important parasites (SolaymaniMohammadi et al., 2005; Maleki et al., 2019). This study has shown that there is a lack of information about protozoan infections in these animals in Iran, and 
further study is required by Iranian health authorities and veterinary organizations to identify wild boar parasites and investigate the role of these parasites in the health of wild boar herds and also in public health.

\section{Acknowledgment}

The authors would like to appreciate very much for kind collaboration of Professor Mousa Tavasuli, Department of pathobiology, Faculty of veterinary medicine, Urmia University of Iran.

\section{References}

1. ASHRAFZADEHA, M. R., H. R. REZAEI, O. KHALILIPOUR and S. KUSZA (2018): Genetic relationships of wild boars highlight the importance of Southern Iran in forming a comprehensive picture of the species' phylogeography. Mamm. Biol. 92, 21-29. 10.1016/j.mambio.2018.04.001

2. BOWMAN, D. (2020): Georgis' Parasitology for Veterinarians. In: Routine diagnostic of swine parasites. China: Saunders.

3. CASTELINO, J. B. and I. V. HERBERT (1972): Investigation of the accuracy of the Clayton-Lane faecal egg flotation technique for estimating the numbers of Hyostrongylus rubidus (Hassall and Stiles, 1892) eggs in pig faeces. J. Helminthol. 46, 387-397. 10.1017/s0022149x00023397

4. CHHABRA, R. C. and R. T. MAFUKIDZE (1992): Prevalence of coccidia in pigs in Zimbabwe. Vet Parasitol. 41, 1-5. 10.1016/0304-4017(92)90002-q

5. DAUGSCHIES, A., S. IMAROM and W. BOLLWAHN (1999): Differentiation of porcine Eimeria spp. by morphologic algorithms. Vet Parasitol. 81, 201-210. 10.1016/s0304-4017(98)00246-5

6. DAUGSCHIES, A., S. IMAROM, M. GANTER and W. BOLLWAHN (2004): Prevalence of Eimeria spp. in sows at piglet-producing farms in Germany. J. Vet. Med. B Infect. Dis. Vet. Public Health 51, 135139. 10.1111/j.1439-0450.2004.00734.x

7. DODANGEH, S., D. AZAMI, A. DARYANI, S. GHOLAMI, M. SHARIF, I. MOBEDI, S. SARVI, E. SOLEYMANI, M. T. RAIMI, M. PIRESTANI, S. GOHARDEHI and R. BASTANI (2018): Parasitic Helminths in Wild Boars (Sus scrofa) in Mazandaran Province, Northern Iran. Iran J. Parasitol. 13, 416-422.

8. ESLAMI, A. and S. FARSAD-HAMDI (1992): Helminth parasites of wild boar, Sus scrofa, in Iran. J. Wildl. Dis. 28, 316-318. 10.7589/0090-3558-28.2.316

9. JEMERŠIĆ, L., J. PRPIĆ, B. ROIĆ, D. ŽELJEŽIĆ and T. KEROS (2019): The wild boar (Sus scrofa) - Victim and ally of the most important viral infections in Europe. Vet. stn. 50, 137-148. (In Croatian).

10. KIA, E. B., A. R. MEAMAR, F. ZAHABIUN and H. MIRHENDI (2009): The first occurrence of
Trichinella murrelli in wild boar in Iran and a review of Iranian trichinellosis. J. Helminthol. 83, 399-402. 10.1017/S0022149X09990319

11. KIA, E. B., H. MIRHENDI, M. REZAEIAN, F. ZAHABIUN and M. SHARBATKHORI (2011): First molecular identification of Sarcocystis miescheriana (Protozoa, Apicomplexa) from wild boar (Sus scrofa) in Iran. Exp. Parasitol. 127, 724-726. 10.1016/j.exppara.2010.11.007

12. LOWENSTEIN, M. and E. KUTZER (1989): The observation of coccidia in swine. Angew Parasitol. 30, 117-126.

13. MALEKI, B., A. H. DALIMI, H. R. MAJIDIANI, M. BADRI, M. GORGIPOUR and A. KHORSHIDI (2019): Parasitic Infections of Wild Boars (Sus scrofa) in Iran: A Literature Review. Infect. Disord. Drug Targets 20, 585-597. 10.2174/18 71526519666190716121824

14. MANSOURI, M., B. SARKARI and G. R. MOWLAVII (2016): Helminth Parasites of Wild Boars, Sus scrofa, in Bushehr Province, Southwestern Iran. Iran. J. Parasitol. 11, 377-382.

15. PILARCZYK, B., A. BALICKA-RAMISZ, A. CISEK, K. SZALEWSKA and $S$ LACHOWSKA (2004): Prevalence of Eimeria and intestinal nematodes in wild boar in north-west Poland. Wiad Parazytol. 50, 637-640.

16. SAlifU, D. A., T. B. MANGA and I. O ONYALI (1990): A survey of gastrointestinal parasites in pigs of the Plateau and Rivers States, Nigeria. Rev. Elev. Med. Vet. Pays Trop. 43, 193-196.

17. SOLAYMANI-MOHAMMADI, S., I. MOBEDI, M. REZAIAN, J. MASSOUD, M. MOHEBALI, H. HOOSHYAR, K. ASHRAFI and M. B. ROKNI (2003): Helminth parasites of the wild boar, Sus scrofa, in Luristan province, western Iran and their public health significance. J. Helminthol. 77, 263-267. 10.1079/JOH2003168

18. SOLAYMANI-MOHAMMADI, S., M. REZAIAN, H. HOOSHYAR, I. MOBEDI and A. R. MEAMAR (2005): The parasites of the Eurasian wild boar, Sus scrofa, in Iran: An emerging implication for public health. Suiform Soundings 5, 26-29.

19. SOLAYMANI-MOHAMMADI, S., M. REZAIAN, H.HOOSHYAR, G.R.MOWLAVI, Z. BABAEI and M. A. ANVAR (2004): Intestinal Protozoa in Wild Boars (Sus scrofa) in Western Iran. J. Wildl. Dis. 40, 801-803. 10.7589/0090-3558-40.4.801

20. SOULSBY, E. J. L. (1982): Helmenths, arthropods and protozoa of domesticated animals. England: Bailliere Tindall.

21. Vetterling, J. M. (1965): Coccidia (Protozoa: Eimeriidae) of swine. J. Parasitol. 51, 897-912.

22. YAEGER, M. J., A. HOLTCAMP and J. A JARVINEN (2003): Clinical coccidiosis in a boar stud. J. Vet. Diagn. Invest. 15, 387-389. 10.1177/104063870301500416

23. YAGHOOBI, K., B. SARKARI, M. MANSOURI, M. H. MOTAZEDIAN (2016): Zoonotic intestinal protozoan of the wild boars, Sus scrofa, in Persian Gulf's coastal area (Bushehr 
province), Southwestern Iran. Vet. World. 9, 10471050. 10.14202/vetworld.2016.1047-1050

24. ZHANG, W. J., L. H. XU, Y. Y. LIU, B. Q. XIONG, Q. L.ZHANG, F. C. LI, Q. Q.SONG,
M. K. KHAN, Y. Q. ZHOU, M. HU and J. ZHAO (2012): Prevalence of coccidian infection in suckling piglets in China. Vet. Parasitol. 190, 51-55. 10.1016/j.vetpar.2012.05.015

\section{Prvo izvješće o prisutnosti Eimeria sp. u euroazijske divlje svinje (Sus scrofa) u Iranu}

Shahrokh SHIRAZI, Arash MOTAGHEDI, Department of Pathobiology, Faculty of Veterinary Medicine, Science and Research Branch, Azad University, Tehran, Iran; Moslem SAFARI, Department of Pathobiology, Faculty of Veterinary Medicine, Shahid Chamran University of Ahwaz, Ahwaz- Iran

Iranske divlje svinje mogu se pronaći $u$ cijeloj zemlji, osim u središnjoj pustinji Irana. Jedno od važnih staništa ove životinje nalazi se u sjevernom planinskom području Irana. Na tom području divlje svine najvjerojatnije izbacuju zaraženi feces, ili prolaze pokraj zaraženih fecesa drugih jedinki što može prouzročiti zoonoze. Međutim, informacije o parazitskim infekcijama divljih svinja $\mathrm{u}$ Iranu su rijetke, stoga je potrebno provesti više studija $u$ svezi parazita ove životinje. U veljači 2019. godine truplo divlje svinje poslano je od strane Odjela za ekologiju provincije Mazandaran Odjelu za veterinarsku parazitologiju Sveučilišta za znanost $\mathrm{i}$ istraživanje $\mathrm{u}$ Teheranu kako bi se proučile njezine parazitske infekcije. Feces i gastrointestinalni trakt su odvojeni i njihov je sadržaj ispitan uporabom dviju metoda flotacije (Willis i Clayton-Lane). Uzorci su poslani i u Parazitološki laboratorij Sveučilišta Urmia za dodatne pretrage. Na temelju veličine i morfoloških čimbenika izoliranih oocista uzorak je bio infestiran protozoom Eimeria; dijagnosticirane su Eimeria porci i Eimeria neodebliecki. Ovo je prvo izvješće o infekciji divlje svinje s protozoom Eimeria sp. u Iranu.

Ključne riječi: Eimeria, infekcija, Iran, oocista, Sus scrofa 